\title{
LAWRENCE VENUTI KODUSTAMISE JA VÕÕRAPÄRASTAMISE DIHHOTOOMIA METAFOORIDE TÕLKEMEETODITE UURIMISE INSTRUMENDINA EESTI-VENE TÕLKES
}

\author{
Ekaterina Kornilitsina, Ingrid Rummo \\ Tartu Ülikool
}

\begin{abstract}
Ülevaade. Eesti-vene meediatõlge on Eesti kultuuriruumis väga tähtsal kohal, kuid samas on seda tõlkesuunda Eesti tõlketraditsioonis siiamaani vähe uuritud. Üks instrumente, mis võib aidata tõlkijal võimalike lahenduste mitmekesisuses orienteeruda, on Ameerika tõlkeuurija Lawrence Venuti kodustava ja võõrapärastava tõlke dihhotoomia, mis seostab tõlkemeetodi valiku tõlke kultuurikontekstiga. Venuti dihhotoomiat kasutatakse tänapäeva tõlketeaduses erinevate tekstielementide tõlke uurimiseks. Nende hulgas on ka metafoor, mis on oma märkimisväärse kultuurilise varieerumise tõttu üks keerulisemaid tõlkeobjekte. Artikkel käsitleb Venuti kodustamise ja võõrapärastamise dihhotoomia kasutamise võimalust metafooride tõlkemeetodite uurimisel eesti-vene tõlkes telesaate "Pealtnägija" näitel. Kuigi "Pealtnägija" eesti-vene tõlkes on eelistatav tõlkemeetod kodustamine, on võõrapärastamist laialt kasutatud mittekonventsionaalsete, kontekstisidusate ja laenmetafooride tõlkimisel.
\end{abstract}

Märksõnad: eesti-vene tõlge, meediatõlge, tõlkemeetod, metafoor, kodustamine, võõrapärastamine, Lawrence Venuti

DOI: https://doi.org/10.12697/jeful.2017.8.1.07

\section{Sissejuhatus}

Uuringud on näidanud, et Eesti venekeelsetel telekanalitel on ulatuslik auditoorium, kuhu ei kuulu mitte ainult vene, vaid ka muu emakeelega Eesti elanikud. Praegu on Eestis võimalik vaadata 347 telekanalit, neist 27 eestikeelset ja 107 venekeelset (Jõesaar 2015). Statistikaandmete järgi vaatas nt 2016. aasta septembris telekanalit ETV+ kokku vähemalt 15 minutit 239000 nelja-aastast ja vanemat televaatajat, mis moodustab umbes $18 \%$ kogu Eesti elanikkonnast ja $72 \%$ Eesti venekeelsest elanikkonnast. ETV+-i kodulehte külastas septembris kokku 66000 kasutajat, kusjuures $70 \%$ neist olid Eestist ja 9\% Venemaalt (ERR-i statistika). 
Olulise osa Eesti venekeelsete telekanalite kavast moodustavad eesti keelest ja muudest keeltest vene keelde tõlgitud saated. Tiheda konkurentsi tingimustes on pakutavate tõlkesaadete kvaliteet äärmiselt oluline. Samas on eesti-vene meediatõlget Eesti tõlketeaduse traditsioonis siiani vähe uuritud. Pole selge, millele peab eesti-vene tõlkija oma töös orienteeruma, milliseid kriteeriume järgima ja milliseid töövõtteid kasutama ning millest lähtuma tõlkemeetodite ja -strateegiate valimisel.

Üks tõlketeoreetilisi kontseptsioone, mis võib aidata tõlkijal võimalike valikute mitmekesisuses orienteeruda, on Ameerika tõlkeuurija Lawrence Venuti kodustamise ja võõrapärastamise dihhotoomia. Venuti mudeli eeliseks võib pidada seda, et see ei piirdu tõlke keeleliste funktsioonidega, vaid võtab arvesse ka kultuurikonteksti. Käesolev artikkel käsitleb Venuti dihhotoomia kasutamise võimalust eesti-vene tõlke uurimisel Eesti kultuuriruumis. Artikli eesmärk on hinnata Venuti kodustamise ja võõrapärastamise opositsiooni sobivust metafooride tõlke uurimiseks eesti-vene tõlkesuunal.

Uurimuse objektiks valiti metafooride eesti-vene tõlked telesaates "Pealtnägija". Lakoffi ja Johnsoni kognitiivse metafoori ehk mõistemetafoori teooria järgi on metafoor üks inimmõtlemise põhjapanevaid mehhanisme, mis baseerub inimese vahetul füüsilisel kogemusel ja võimaldab tal mõtestada keerulisi abstraktseid kontseptsioone (Lakoff ja Johnson 2011). Seetõttu on mitte ainult ilukirjanduse keel, vaid ka üldkeel läbinisti metafoorne ning pole imekspandav, et meediakeeles esineb rohkesti metafoore. Kuigi inimeste füüsiline kogemus on kõigis maailma nurkades enamjaolt sarnane, on metafooridele siiski omane märkimisväärne kultuuriline varieerumine, mistõttu on nad üks keerulisemaid tõlkeobjekte.

\section{Venuti kodustamise ja võõrapärastamise dihhotoomia}

Venuti dihhotoomia eelduseks oli 1980-ndate lõpus - 1990-ndate alguses tõlketeaduses toimunud oluline muutus, mida Bassnett ja Lefevere (1990: 8) on nimetanud kultuuriliseks pöördeks (ingl cultural turn). Kui varem käsitleti tõlkimist kui ülekannet lähtekeelest sihtkeelde, siis nüüd hakati tõlkeprotsessi seostama eelkõige kultuuriga ja vaatlema kui keerulist suhtlust lähtekultuuri ja sihtkultuuri vahel (Munday 2009: 179). Üks silmapaistvamaid kultuurilise pöörde suuna esindajaid on USA tõlkeuurija Lawrence Venuti, kes on Kjetil Myskja (2013: 2) sõnul tänapäeva tõlketeaduses "mõjuv, kuid samas vastuoluline" isik. 
Oma põhjapanevas teoses “The Translator's Invisibility" (2008), mille esmatrükk ilmus aastal 1995, käsitleb Venuti tõlkeprotsessi kui lähteteksti elementide asendamist sihtteksti elementidega, milles võtmerolli mängib tõlkija interpretatsioon. Tõlkeprotsessi lahutamatuks omaduseks on Venuti arvates vägivaldsus (ingl violence), kuna tõlge ei ole muud kui lähteteksti taasloomine sihtkultuuri väärtuste, uskumuste ja muude kontseptsioonide järgi (Venuti 2008: 14). Kui lähtetekst on võimaluste kogum, siis sihttekstis realiseeruvad need võimalused vaid ühel teatud viisil, mis sõltub nii tõlkija isiksusest kui ka kultuurilisest ja sotsiaalsest olukorrast ühiskonnas, kuhu ta kuulub (Venuti 2008: 13).

Tõlkija ees seisva valiku iseloomustuseks on Venuti kasutanud 19. sajandi saksa teoloogi ja filosoofi Friedrich Schleiermacheri ideid (Venuti 2008: 13). Schleiermacher (2005: 149) eristas kaht tõlkemeetodit sõltuvalt sellest, kas tõlge lähendab autorit lugejale või vastupidi, lähendab lugejat autorile. Venuti (2008: 15) nimetab neid meetodeid vastavalt kodustamiseks (ingl domestication) ja võõrapärastamiseks (ingl foreignisation). Kodustamine on Venuti (2008: 15) definitsiooni järgi lähteteksti taandamine sihtkultuuri väärtustele ning võõrapärastamine on lähteteksti keelelise ja kultuurilise eripära tunnistamine ja säilitamine. Kodustav tõlge põhineb Venuti (2008: 17) sõnul ettekujutusel humanistlike ideede universaalsusest, millega on tihedalt seotud Piibli tõlkimise traditsioon. Selle ettekujutuse järgi ei ole kultuurilised erinevused olulised ning neid võib eirata, kui nad segavad mõtte edasiandmist. Võõrapärastav tõlge rõhutab seevastu kultuuridevahelisi erinevusi ja väärtuste suhtelisust. On oluline rõhutada, et võõrapärastamine ei ole Venuti (2008: 15-16) käsitluses võõra otsene ülekandmine lähtetekstist sihtteksti, vaid pigem sihtkeele ja -kultuuri normide teadlik rikkumine. Seega võivad võõrapärastamise kriteeriumid sõltuvalt konkreetsest tõlkest erineda.

Kodustamise ja võõrapärastamise opositsioon iseloomustab Venuti järgi tõlkimisprotsessi kõigepealt sotsiokultuurilisel ja eetilisel tasandil. Oma uurimistöös on Venuti mh kritiseerinud Briti ja Ameerika tõlketraditsioonis valitsevat püüdlust ladususe (ingl fluency) poole ning on välja pakkunud võõrapärastamisel põhineva tõlkemeetodi, mida on nimetanud resistentsuseks (ingl resistance). Resistentsus on Venuti (2008: 18) definitsiooni järgi tõlkemeetod, mis osutab vastupanu sihtkultuuri väärtustele, et rõhutada lähteteksti keelelist ja kultuurilist eripära. Võõrapärastamine on seega Venuti käsitluses tõlkemeetod, mis on võimeline "demokraatlike geopoliitiliste suhete huvides vastu seisma etnotsentrismile ja rassismile, kultuurilisele nartsissismile ja imperialismile" (Venuti 2008: 16). Hoolimata sellest, et Venuti seostab kodustava 
ja võõrapärastava tõlke opositsiooni kõigepealt postkoloniaalse maailma tõlketraditsioonidega, saab tema arvates võõrapärastamise mõistet sama hästi rakendada tõlkimisele ükskõik mis keelest ja mis keelde (Venuti 2008: 19).

\section{Venuti dihhotoomia kriitikat}

Venuti kodustamise ja võõrapärastamise dihhotoomia on pälvinud tõlkeuurijate seas positiivset vastukaja. Samas on Venuti ideid ka palju kritiseeritud.

Üheks Venuti dihhotoomia puuduseks arvatakse seda, et tema kasutatavad mõisted pole selgelt defineeritud. Venuti on aastate jooksul enda eelistatud tõlkemeetodi nimetamiseks kasutanud kolme sünonüümset terminit: võorapärastamine, resistentsus ja hilisemates töödes minoriseeriv tõlge (Venuti 1998, 2008). Maria Tymoczko (2012: 176) täheldab, et terminite rohkuse tõttu Venuti töödes saab nendega liiga vabalt opereerida. Võõrapärastamine ei tähenda Tymoczko arvates veel originaalteksti eripära säilitamist, kuna tõlkimine võib muuta originaalteose "tekstuaalset ja kultuurilist representatsiooni" (nt teha ilukirjanduslikust tekstist mitteilukirjandusliku), hoolimata sellest, et tõlge ise vastab Venuti võõrapärastamise kriteeriumitele (Tymoczko 2012: 177).

Võõrapärastava ja kodustava tõlke tuvastamine ei vasta Tymoczko (2012: 179) arvates kopeeritavuse ja ülekantavuse nõudmisele, mida esitatakse igale teaduslikule meetodile, ning sõltub iga konkreetse uurija isiklikust hinnangust. Venuti võõrapärastamise ja resistentsuse mõisted ei ole Tymoczko arvates üldse defineeritavad formaalse ega funktsionaalse kategooriana, seetõttu on neid raske tõlkeuuringutes rakendada. Samuti ei leidu Venuti töödes võõrapärasuse (või resistentsuse) kvantitatiivseid kriteeriume ehk Tymoczko sõnul puudub vastus küsimusele "Kui palju resistentsust peab ühes tõlkes olema, et see resistentseks lugeda?" (ibid.).

Tymoczko juhib tähelepanu ka sellele, et Venuti kriteeriumid on pigem normatiivsed kui deskriptiivsed: kodustava ja võõrapärastava tõlke vahel annab ta selgelt eelistuse võõrapärastamisele. Kuna Venuti käsitleb oma teostes eelkõige Ameerika Ühendriikides väljakujunenud tõlketraditsiooni, jõuab Tymoczko (2012: 181) järeldusele, et võõrapärastamise ja kodustamise opositsioon on rakendatav vaid tõlkimisele "võimsates lääneriikides" ega peegelda olukorda väiksemates maades.

Vastuväited on seotud ka sellega, et Venuti töödest ei selgu, mis tasemel saab kodustamise ja võõrapärastamise mõisteid rakendada: 
kas tervikteksti, tekstilõigu, lause või üksiku elemendi (nt reaali või idiomaatilise väljendi) tasemel? Baker (2007: 152) arvab, et Venuti dihhotoomia ei ole rakendatav tervikteksti analüüsiks, sest tõlkija ei vali kunagi terve tõlkimistöö käigus üht ja sama tõlkemeetodit, vaid "pendeldab" eri valikute vahel. Kaldjärv (2007: 67) täheldab ka, et oleks raske leida teksti, kus kõigil teksti tasandeil oleks järjepidevalt kasutatud vaid kodustamist või võõrapärastamist. Tema sõnul ei muuda võõrapäraste elementide olemasolu tõlget veel automaatselt võõrapärastavaks ning täiesti võõrapärane tõlge ei ole üldse võimalik, kuna see tähendaks sisuliselt teksti mittetõlkimist (Kaldjärv 2007: 68).

\section{Venuti dihhotoomia kasutamine metafooride tõlkestrateegiate uurimiseks}

Kaldjärve arvates toimib kodustamise ja võõrapärastamise opositsioon hästi vaid reaalide tõlkestrateegiate uurimisel, millega võõrapärastamine Kaldjärve arvates tavaliselt piirdubki (Kaldjärv 2007: 67). Siiski on Venuti dihhotoomiat edukalt kasutatud ka teiste tekstielementide tõlke uurimiseks. Üks põhjapanevaid uurimusi, kus rakendatakse Venuti ideid, on Pederseni analüüs (2005) subtiitrites leiduvate keeleväliste kultuurispetsiifiliste viidete (ingl extralinguistic culturebound reference ehk $E C R$ ) tõlkimisest ${ }^{1}$. Keeleväline kultuurispetsiifiline viide on Pederseni (2005: 2) definitsiooni järgi lähtekeelne väljend, mis viitab mõnele lähtekultuuri elemendile. Tüüpilised keelevälised kultuurispetsiifilised viited on reaalid, kuid Pederseni enda sõnul (ibid.) saab seda mudelit kohandada ka nt idioomide tõlkestrateegiate uurimiseks. Venuti kodustamise ja võõrapärastamise ${ }^{2}$ opositsiooni põhjal on Pedersen (2005: 3) välja töötanud skaala, kuhu võib paigutada tõlkestrateegiad sõltuvalt nende võõrapärastavast või kodustavast efektist. Võõrapärastamise kriteerium on Pederseni uurimuses tõlkija sekkumine lähteteksti, kuna "vaevalt hakkab subtiitrite tõlkija [lähteteksti] sekkuma, et teha sihtteksti võõrapärasemaks" ("it would be unlikely for a subtitler to intervene to make a TT [Target Text] more foreignized")

1 Mõiste tõlge asemel kasutab Pedersen terminit edastus (ingl rendering), kuna kõik tema vaadeldavad strateegiad ei sisalda tõlkimist (Pedersen 2005: 3).

2 Tõlkestrateegiate iseloomustuseks kasutab Pedersen termineid lähtekeelele ja sihtkeelele orienteeritud (ingl Source Language oriented ja Target Language oriented), kuna terminid kodustamine ja võorapärastamine ei sobi tema arvates juhul, kui tegu on tõlkimisega "suuremast" keelest "väiksemasse" (Pedersen 2005: 3). 
(Pedersen 2005: 9). Siin võib näha vastuolu Venuti võõrapärastamise definitsiooniga, kuna Venuti järgi ei ole võõrapärastamine võõrapärasuse otsene ülekandmine lähtetekstist sihtteksti, vaid pigem sihtkeele normide teadlik rikkumine, mis annab märku lähteteksti võõrapärasusest.

Pedersen (2005: 9) jaotab tõlkestrateegiad kahte gruppi sõltuvalt sellest, kas tõlkija sekkumine on minimaalne või maksimaalne. Võõrapärastavate ehk lähtekeelele orienteeritud tõlkestrateegiate hulka kuuluvad Pederseni arvates tekstielemendi säilitamine (ingl retention), täpsustamine (ingl specification) ja mingil määral ka otsetõlge (ingl direct translation). Kodustavate ehk sihtkeelele orienteeritud strateegiate hulka kuuluvad seevastu üldistamine (ingl generalisation), asendamine (ingl substitution) ja väljajätmine (ingl omission), ka mõned otsetõlke juhtumid. Pedersen täheldab, et praktikas erinevaid tõlkestrateegiad sageli kombineeritakse (Pedersen 2005: 9).

Mitu tõlkeuurijat on kasutanud Pederseni loodud kodustamisevõõrapärastamise skaalat $\mathrm{ka}$ teiste tekstielementide tõlke analüüsimiseks. Näiteks võib tuua Penttilä ja Muikku-Werneri (2012) artikli, kus Venuti dihhotoomiat ja Pederseni skaalat on kasutatud idiomaatiliste väljendite tõlkestrateegiate uurimiseks. Idiomaatiline väljend on Penttilä ja Muikku-Werneri käsitluses mõiste, mis on lähedane nii Pederseni keelevälisele kultuurispetsiifilisele viitele kui ka meie uurimuse objektile ehk metafoorsele väljendile. Penttilä ja Muikku-Werner (2012: 124-125) täheldavad, et igal idiomaatilisel väljendil on lisaks denotatiivsele olemas ka konnotatiivne tähendus ehk sotsiaalsed konnotatsioonid, ajaloolised viited jms.

Idioomi konnotatiivne tähendus võib Penttilä ja Muikku-Werneri järgi asuda nn kultuuridevahelisel alal (ingl transcultural area) ehk olla tuttav nii lähte- kui ka sihtkultuuri esindajatele (Penttilä, MuikkuWerner 2012: 127). Kultuuridevaheline ala (kus kultuuriline ülekanne toimub siiski vaid ühes suunas) on välja kujunenud viimasel ajal nt inglise ja soome keele vahel, mistõttu ingliskeelsete idioomide tõlkimiseks kasutatakse Soome meedias üha rohkem otsetõlget (Penttilä, MuikkuWerner 2012: 133-135). Kuigi tänapäeval on Penttilä ja MuikkuWerneri (2012: 136) sõnul normiks idioomide kodustamine, arvavad nad, et tõlkija peaks kaaluma ka idioomi võõrapärastava tõlke võimalust, eriti juhul, kui selle konnotatiivne tähendus lähtekeeles on oluline tervikteksti mõistmiseks. Penttilä ja Muikku-Werner (2012: 124) rõhutavad, et kodustamise ja võõrapärastamise dihhotoomia ei ole absoluutne ning need tõlkemeetodid on ühe ja sama kontiinumi äärealad. 
Belikova (2010) on kasutanud Pederseni mudelit poliitiliste metafooride tõlkestrateegiate uurimiseks soome-vene tõlkes. Valik metafoorse väljendi kodustamise või võõrapärastamise vahel sõltub Belikova (2010: 2) arvates eelkõige metafoori konventsionaalsusest: üldlevinud (sh "surnud") metafooridel on tavaliselt olemas väljakujunenud tõlkevasted, innovatiivsete metafooride tõlkimise puhul valib tõlkija kodustava või võõrapärastava tõlke vahel.

Oma uurimuses kasutab Belikova samuti Pederseni kodustamisevõõrapärastamise skaalat, kuid tema arvates ei saa kõiki tõlkija lahendusi üheselt arvata kas võõrapärastava või kodustava tõlke hulka, sellepärast eraldab ta oma skaalal ka neutraalse tõlke ala (Belikova 2010: 5). Neutraalne tõlge on Belikova (2010: 7) definitsiooni järgi metafoori säilitamine, mis on sama võõras nii lähte- kui ka sihtkeelse teksti lugejale.

Belikova lähenemisviisi uudsus seisneb ka selles, et erinevalt ülalmainitud uurijatest ei seosta ta üksikuid tõlkestrateegiaid kindlalt skaala võõrapärastamise või kodustamise alaga, vaid arvab, et üks ja sama strateegia võib olla erinevate tõlkemeetodite tööriistaks (Belikova 2010: 4). Seega tekib lineaarse skaala asemel kontiinum, kus piirid eri tõlkemeetodite vahel on hajusad (vt Belikova 2010: 5).

Belikova artikkel on ülalmainitud uurimuste seas ainuke, kus on püütud välja arendada võõrapärastamise kvantitatiivseid kriteeriume. Tõlke võõrapärasuse kriteeriumiks on Belikova uurimuses sihtkeelse metafoorse väljendi esinemissagedus keelekorpuses ja internetis (Belikova 2010: 4). Kuigi Belikova hinnangul võib näiteks $100 \mathrm{mln}$ sõnaga keelekorpuses 17 korda esinevat fraasi pidada sihtkeele suhtes võõrapäraseks, 600 korda esinevat fraasi aga emakeelseks (Belikova 2010: 5-6), ei jõuta tema uurimuses siiski kindla võõrapärasuse kriteeriumini.

Ülaltoodud uurimistööd näitavad, et Venuti dihhotoomiat kasutatakse edukalt väga erinevate tekstielementide tõlkemeetodite uurimiseks, kusjuures uurijad tõlgendavad Venuti ideid üsna vabalt ning määravad ise kodustava ja võõrapärastava tõlke kriteeriume vastavalt uurimisobjekti eripärale. Ka käesolevas uurimuses kasutatakse Venuti dihhotoomiat ülalmainitud tõlkeuurijate eeskujul pigem vundamendina, millele rajatakse analüüsi täpsemad kriteeriumid. 


\section{Materjal ja meetod}

Analüüsitava materjali moodustasid oli 2014. ja 2016. aastal eetris olnud telesaade "Pealtnägija" ja selle tõlked vene keelde. 2014. aastal kasutati "Pealtnägija" venekeelses versioonis subtiitreid ning 2016. aastal dublaaži. Uurimise käigus analüüsiti kuut juhuslikult valitud saadet pikkusega umbes 45 minutit.

Uurimise objektiks olid eestikeelsed metafoorsed väljendid ja nende venekeelsed tõlkevasted. Metafoorse väljendi all mõisteti käesolevas uurimuses väljendit ${ }^{3}$, mille taga on mõni Lakoffi mõistemetafoor ehk projitseerivad suhted kahe kognitiivse valdkonna vahel. Kokku analüüsiti 604 metafoorse väljendi tõlget, mida sisaldavatest lausetest koostati paralleelkorpus.

Analüüsi meetodiks oli lähte- ja sihttekstis kasutatud metafoorsete väljendite võrdlemine, mille abil selgitati välja kasutatud tõlkemeetodid. Tõlkemeetodi ${ }^{4}$ all mõistetakse käesolevas uurimuses tõlkimisprotsessi üldist suundumust ehk seda, kas metafoori sobitatakse sihtkeele ja -kultuuri normidega või vastupidi, antakse märku selle pärinemisest teisest keelest ja kultuurist.

Analüüsi alusel jaotati väljendid ja nende tõlked kolme gruppi: kodustav, neutraalne ja võõrapärastav tõlge. Väljendite jaotamine gruppidesse põhines kahel kriteeriumil: 1) mil määral on algupärast mõistemetafoori tõlkeprotsessi käigus muudetud ning 2) kuidas tulemus mõjub sihtkeelsele lugejale, sõltumata sellest, milliseid konkreetseid tõlkestrateegiaid on tõlkija kasutanud.

Võõrapärastavaks peetakse käesolevas uurimuses tõlget, kus tõlkija sekkumine lähtekeelsesse metafoori oli minimaalne ning tulemus sihtkeele ja -kultuuri suhtes võõrapärane. Neutraalseks peetakse sellist tõlget, mille puhul eesti- ja venekeelne metafoor langevad kokku ning tõlke tulemus ei mõjunud sihtteksti lugejale võõrapärasena, hoolimata sellest, et tõlkija sekkumine lähteteksti oli minimaalne. Kodustavaks peeti tõlget, mille puhul tõlkija oli lähtekeelset väljendit aktiivselt sobitanud sihtkeele ja -kultuuri normidega, nii et see ei mõjunud sihtkultuuri

3 Mõistemetafoori teooria ei määra rangelt seda, kuidas näevad välja konkreetsed mõistemetafoori esinemisjuhtumid keeles, ehk neid võib otsida grammatilise konstruktsiooni, fraasi, lause, tekstiosa või teksti tasandil. Käesolevas uurimuses otsiti metafoorseid väljendeid fraasi tasandil.

4 Tõlketeaduses ei ole siiamaani välja kujunenud tõlkemeetodi, -strateegia ja -tehnika üldkasutatavaid definitsioone ning nende terminite kasutus sõltub konkreetse uurija eelistusest (vt Molina ja Albir 2002). 
lugejale enam võõrapärasena. Kodustava tõlke hulka arvati ka lähtekeelse väljendi väljajätmine.

Kriteeriumid, mida kasutati käesolevas uurimuses tõlkemeetodi hindamiseks, on võimalik kokku võtta järgmise tabeli kujul.

Tabel 1. Tõlkemeetodi hindamiskriteeriumid

\begin{tabular}{l|c|c} 
& $\begin{array}{c}\text { Tõlkija } \\
\text { sekkumine }\end{array}$ & $\begin{array}{c}\text { Tõlge mõjub } \\
\text { sihtkultuuri lugejale }\end{array}$ \\
\hline Võõrapärastav tõlge & minimaalne & võõrapärasena \\
\hline Neutraalne tõlge & minimaalne & loomulikuna \\
\hline Kodustav tõlge & maksimaalne & loomulikuna
\end{tabular}

Tõlke võõrapärasuse hindamise instrumendina kasutati nii uurijate keeletaju kui ka vene keele rahvuslikku korpust (VKRK), kontrolliti ka metafoorsete väljendite esinemist internetis.

\section{Tulemused}

Kõige levinumaks tõlkemeetodiks analüüsitud materjalis oli kodustamine. Kodustavat tõlget on kasutatud 362 juhul 604-st ehk 60\%-1 juhtudest. Metafoorsete väljendite kodustamiseks kasutati erinevaid tõlkestrateegiaid, sh metafoori asendamist, parafraseerimist, üldistamist, väljajätmist ja muid võtteid.

Tabelis 2 on esitatud uurimuse arvulised andmed saadete kaupa.

Tabel 2. Telesaates "Pealtnägija" metafoorsete väljendite tõlkimisel kasutatud tõlkemeetodid

\begin{tabular}{l|c|c|c|c} 
& $\begin{array}{c}\text { Kodustav } \\
\text { tõlge }\end{array}$ & $\begin{array}{c}\text { Neutraalne } \\
\text { tõlge }\end{array}$ & $\begin{array}{c}\text { Võõra- } \\
\text { pärastav } \\
\text { tõlge }\end{array}$ & Kokku \\
\hline "Pealtnägija", 06.09.2014 & 52 & 35 & 7 & 94 \\
\hline "Pealtnägija", 13.09.2014 & 64 & 57 & 9 & 130 \\
\hline "Pealtnägija", 27.09.2014 & 42 & 30 & 7 & 79 \\
\hline "Pealtnägija", 23.01.2016 & 85 & 27 & 8 & 120 \\
\hline "Pealtnägija", 12.03.2016 & 53 & 20 & 8 & 81 \\
\hline "Pealtnägija", 16.04.2016 & 66 & 29 & 5 & 100 \\
\hline & 362 & 198 & 44 & $\mathbf{6 0 4}$
\end{tabular}


Näites 1 esineb eestikeelses tekstis metafoorne väljend parklate kasumid on kokku kuivanud. Eesti keele seletav sõnaraamat on verbi kokku kuivama otseseks tähenduseks märgitud 'kuivetuma, kõhetuma, kehaliselt otsekui kokku tõmbuma' (nt vanainimene kuivab kokku) ning ülekantud tähenduseks 'kahanema, väheseks, napiks jääma' (EKSS). Teisisõnu põhineb see metafoorne väljend mõistemetafooril VÄHENEMINE ON KUIVAMINE. Vene keeles seda mõistemetafoori ei esine, seetõttu asendas tõlkija selle venekeelsele lugejale harjumuspärasema orientatsioonimetafooriga SUUR ON ÜLEVAL, VÄIKE ON ALL: прибыль оm парковок упала 'parklate kasum on langenud'.

\section{Näide 1}

Saharovi mitu konkurenti väitsid "Pealtnägijale", et parklate kasumid on kokku kuivanud ja ühe keskmise suurusega parkla pealt võib mustalt teenida 1000-2000 eurot kuus.

Несколько конкурентов Сахарова говорили “Очевидцу”, что прибыль от парковок упала, с одной средней парковки можно по-черному заработать 1000-2000 евро в месяц.

'Mitu Saharovi konkurenti rääkisid "Pealtnägijale", et parklate kasum on langenud, ühe keskmise parkla pealt võib mustalt teenida 1000-2000 eurot kuus.'

“Pealtnägija”, 06.09.2014

Käesolevat analüüsi kinnitavad ka korpuse andmed: vene keele rahvuslikus korpuses esineb väljend прибыль упала 'kasum on langenud' 92 korda, прибыль усохла 'kasum on kokku kuivanud' ei esine aga kordagi. Kuigi Google'i otsingumootoriga leiame internetist 119 venekeelset teksti, kus esineb väljend прибыль усохла 'kasum on kokku kuivanud' (väljend прибыль упала 'kasum on langenud' esineb seevastu 37800 venekeelses tekstis), on paljud neist tekstidest tõlgitud eesti keelest. Metafoorse väljendi sõnasõnalist tõlget saab sellisel juhul pidada võõrapärastamise näiteks.

Teisel kohal oli analüüsitud materjalis neutraalne tõlge: seda tõlkemeetodit kasutati 198 juhul 604-st ehk 33\%-1 juhtudest. Neutraalse tõlke strateegiaks oli otsetõlge ehk sõnasõnaline tõlge. Tõlkimise käigus oli tõlkija mõnikord teinud ka vajalikke grammatilisi või süntaktilisi muudatusi, mis ei puudutanud siiski mõistemetafoori kui sellist. Näites 2 on esitatud juhtum, kus eesti- ja venekeelne mõistemetafoor langevad kokku. Eesti keele seletavas sõnaraamatus on verbi kõikuma otseseks tähenduseks märgitud 'edasi-tagasi v üles-alla liikuma, õõtsuma', ülekantud tähenduseks aga 'mitte ühesugune olema, teatud piirides vahelduma, ebakindel olema' (EKSS). Nii eesti- kui ka venekeelne 
metafoorne väljend põhinevad käesoleval juhul ühel ja samal mõistemetafooril KVALITEET ON ESE ja sellest tuleneval metafooril (KVALITEEDI) VAHELDUMINE ON ÕÕTSUMINE.

\section{Näide 2}

Raske on konkreetseid juhtumeid kommenteerida, kui materjalide kvaliteet võib olla kõikuv.

Трудно комментировать конкретные случаи, если качество материалов может колебаться.

'Raske on kommenteerida konkreetseid juhtumeid, kui materjalide kvaliteet võib kõikuda.'

“Pealtnägija”, 27.09.2014

Vene keele rahvuslikus korpuses ülaltoodud metafoorset väljendit küll ei leidu, kuid internetis esineb fraas качество колеблется 'kvaliteet kõigub' 3700 korda ja качество может колебаться 'kvaliteet võib kõikuda' 1960 korda. Sellest saab järeldada, et metafoor ei ole vene keele suhtes täiesti võõrapärane, kuigi ei ole ka massiliselt levinud.

Võõrapärastavat tõlkemeetodit kasutati analüüsitud materjalis kõige vähem: 44 juhul 604-st ehk 7\%-1 juhtudest. Võõrapärastamise peamiseks strateegiaks oli otsetõlge, mõnikord kasutas tõlkija võõrapärasuse rõhutamiseks ka muid vahendeid, nt pani fraasi jutumärkidesse või varustas selle kommentaariga.

Näites 3 on vene keelde sõna-sõnalt tõlgitud metafoorne väljend räpane kohtuvaidlus. Eesti keele seletava sõnaraamatu järgi on sõna räpane otsene tähendus 'kasimata, määrdunud, ropane', piltlik aga 'alatu, nurjatu'. Mõistemetafoori AUSUS ON PUHTUs järgi saab moodustada piltlikke väljendeid ka vene keeles, nt räpane laim - грязная клевета, räpane skandaal - грязный скандал, kuid mitte kõigile sellel mallil põhinevatele eestikeelsetele fraasidele ei leidu vene keeles analoogiat. Väljendit грязный спор 'räpane vaidlus' vene keele rahvuslikus korpuses ei leidu ning internetis esineb see vaid 510 korda ja sageli jutumärkides.

\section{Näide 3}

Kohe pärast kohtumaratoni algust kadus võlgu jäänud Parklinn Grupp orbiidilt, Saharov asutas kaks uut firmat ning justnagu ei olekski mingit räpast kohtuvaidlust, jätkas linn talle oma vara üürimist.

Сразу после начала судебного марафона задолжавшая фирма Parklinn Grupp исчезла с орбиты, Сахаров основал две новые фирмы и, как будто бы не было никакого грязного судебного спора, город вновь сдавал ему в аренду свое имущество. 
'Kohe pärast kohtumaratoni algust kadus võlgu jäänud firma Parklinn Grupp orbiidilt, Saharov asutas kaks uut firmat ning justnagu ei olekski mingit räpast kohtuvaidlust, andis linn talle uuesti oma vara rendile.'

"Pealtnägija", 13.09.2014

Kui kodustamise tuvastamine tõlkes ei valmistanud uurimuse autoritele erilisi raskusi, siis neutraalse ja võõrapärastava tõlke eristamine ei olnud alati sugugi nii lihtne. Analüüsitud tõlgetes esines ka palju väljendeid, mida saab artiklis sätestatud kriteeriumide järgi arvata kas neutraalse või võõrapärastava tõlke hulka, kuid nad jäävad Venuti opositsioonist väljapoole.

Kuna Venuti kodustamise ja võõrapärastamise opositsioon põhineb kõigepealt Briti ja Ameerika tõlketraditsioonil, on tema mudeli järgi tõlkeprotsessis kaks osalist: lähte- ja sihtkeel, kusjuures sihtkeelt ja -kultuuri iseloomustab kõrgem staatus ja võimupositsioon. Praktikas tuleb aga ette situatsioone, kus lähte- ja sihtkeele suhted on keerulisemad ning tõlkeprotsessi sekkub ka kolmas osaline: mõni keel, mis mõjutab oluliselt nii lähte- kui ka sihtkeelt. Eesti-vene-eesti tõlke puhul on selliseks keeleks inglise keel: nii eesti kui ka vene keeles levib viimasel ajal rohkesti anglitsisme, sh ingliskeelsed laenmetafoore. Seejuures on loomulik, et laenmetafooride juurdumise protsessi kiirus varieerub sõltuvalt keelest ja konkreetsest metafoorist ning üks ja sama metafoor ei pruugi kahes keeles sama hästi koduneda.

Näites 4 on tegemist ingliskeelse metafoorse väljendi the fledg(e)ling year 'kollanoka-aasta' toortõlkega, mille tõlkija on omakorda sõnasõnalt vene keelde tõlkinud. Väljend kollanokk-желторотьй птенеu, on mõlemas keeles üsna tavapärane, kuid fraas kollanoka-aasta esineb eestikeelses internetis vaid kümmekond korda ning venekeelses mitte ühtegi korda. Metafoori võõrapärasust mõlemas keeles rõhutab väljend niinimetatud - т.н. (так называемылй). Kuigi formaalselt kuulub see juhtum võõrapärastava tõlke hulka, ei ole tõlke võõrapärasus tingitud mitte lähtekeele eripära säilitamisest, vaid sellest, et lähtekeelne väljend on omakorda toortõlge kolmandast keelest.

\section{Näide 4}

Esimese Eesti kodanikuna NFL-i jõudnud Hundil on möödas küll alles esimene, niinimetatud kollanoka-aasta, kuid sellegipoolest on kogu liiga üks pikem ja jõulisem mängija murdnud ennast siinsete fännide südameisse.

Для Хунтя, первого гражданина Эстонии в NFL, прошел лишь первый год, т.н. год желторотого птенца, но, несмотря на это, он один из самых высоких и сильных игроков в лиге, и он завоевал сердца фанатов. 
'Hundil, esimesel Eesti kodanikul NFL-is on möödas alles esimene aasta, nn kollanoka-aasta, kuid vaatamata sellele on ta üks kõige pikemaid ja jõulisemaid mängijaid liigas ning on võitnud fännide südamed.'

"Pealtnägija", 13.09.2014

Analüüsitud materjalis esines üsna palju tõlkepaare, mille aluseks on tõlkelaen kolmandast keelest. Mõned neist on nii lähte- kui ka sihtkeeles suhteliselt võrdselt juurdunud, nt rahaреsи - отмывание денег (ingl money laundering), mõned kõlavad seevastu vene keeles võõrapäraselt, nt riiulifirma - полочная фирма (ingl shelf company), narkoтииl - наркомул (ingl drug mule). Siin tuleb aga arvesse võtta seda, et mitte ainult inglise keel ei mõjuta mõlemat keelt, vaid eesti keele ja eestivenelaste vene keele vahel on ka vastastikune mõju ${ }^{5}$. Eesti-vene keelekontakte ei ole autorite teada veel metafoori tasandil uuritud, kuid võib oletada, et eesti keeles juurdunud ingliskeelne metafoorne väljend võib keelekontaktide kaudu tulla hõlpsasti ka eestivenelaste vene keelde.

Võõrapärasuse allikaks tõlkes ei pruugi olla ainult laenmetafoorid, vaid ka tegijaspetsiifilised ehk mittekonventsionaalsed metafoorid, mis kannavad endas lisaks tähenduslikule ka stilistilist komponenti. Mittekonventsionaalse metafoori puhul võib tõlkija valida võõrapärastava tõlkemeetodi, et säilitada individuaalse kõnepruugi eripära.

Näites 5 on tegemist lõiguga intervjuust Hannes Võrnoga, kus oli juttu Eesti Olümpiakomitee tegevusest. Kritiseerides olümpiakomitee tegevust, kasutas Hannes Võrno metafoorset konstruktsiooni verstapostid või siis piiripostid on natukene lääbakil (...) raha poole võ $i$ poliitika poole, võimu suunas. Eesti keele seletava sõnaraamatu järgi on sõnal verstapostid olemas ülekantud tähendus 'oluline, murranguline sündmus', nt ajaloo verstapostid (EKSS). Samuti võib oletada, et sõna lääbakil kasutus põhineb mõistemetafooril SIRGE ON HEA, KALDNE/ KÕVER ON HALB. Originaalse metafoori keerukus ja mitmekihilisus võis olla sõnasõnalise tõlkestrateegia valiku põhjus.

\section{Näide 5}

Ja see on see, nagu ma ka ühes kommentaaris ütlesin, et verstapostid või siis piiripostid on natukene lääbakil. Ja see tähendab seda, et nad on lääbakil kas siis raha poole või poliitika poole, võimu suunas.

Как я сказал в одном из своих комментариев, верстовые столбы накренились в направлении денег, политики, власти в целом.

5 Eesti-vene keelekontaktide kohta vt nt Verschik 2016. 
'Nagu ma ühes oma kommentaaris ütlesin, verstapostid on raha, poliitika, võimu tervikuna suunas kaldunud.'

“Pealtnägija”, 23.01.2016

Üheks Venuti võõrapärastamise ja kodustamise opositsiooni puuduseks on ka see, et see mudel ei arvesta võimalike tõlkevigadega. Sihtkeele normide rikkumise põhjuseks ei ole alati teadlik võõrapärastav tõlge, mille abil tõlkija üritab lähteteksti eripärast märku anda, vaid ka juhuslikud tõlkevead, mis on tingitud tõlkija väsimusest, tähelepanematusest või puudulikust väljendusoskusest. Näites 6 oli tõlkija eesmärk ilmselt lähtekeelne väljend kodustada, kuid tulemus jäi siiski sihtkeele suhtes võõrapäraseks.

\section{Näide 6}

Ma loodan, et selliste tegudega, mida nüüd geikogukond on üles näidanud, on see väide sajaprotsendiliselt ümber lükatud!

Надеюсь, что этими делами, которые показало гей-сообщество, это утверждение полностью опрокинуто!

'Loodan, et selliste tegudega, mida geikogukond on üles näidanud, on see väide täiesti ümber aetud!'

“Pealtnägija”, 06.09.2014

Tõlkevea põhjus on selles, et eestikeelset verbi ümber lükkama on võimalik vene keelde tõlkida kahel viisil: otseses tähenduses опрокинуть '(eset) ümber ajama, ümber lükkama' ning ülekantud tähenduses опровергнуть '(väidet) ümber lükkama'. Vene keele normidele vastaks käesoleval juhul teine variant: утверждение опровергнуто 'väide on ümber lükatud'.

\section{Arutelu ja kokkuvõte}

Metafooride tõlkimise analüüs telesaate "Pealtnägija" näitel tõi välja, et valdavaks tõlkemeetodiks eesti-vene meediatõlkes on kodustamine, mida kasutati $60 \%-1$ juhtudest. Kodustava meetodi ulatuslikku kasutamist võib seletada sellega, et "Pealtnägija" ühendab info- ja meelelahutuslikke funktsioone ning kodustatud tõlge hõlbustab oluliselt info vastuvõtmist. Samas kannavad metafoorid endas lisaks konnotatiivsele tähendusele ka denotatiivset, mis võib kodustamise tulemusel kaduma minna. 
Uuritud materjalis oli teisel kohal neutraalne tõlge, mida kasutati 33\%-1 juhtudest. See räägib eesti- ja venekeelsete metafooride sarnasusest, mida võib omakorda seletada nii kultuurikontaktidega kui ka inimkogemuse universaalsusega.

Kõige vähem kasutati metafoorsete väljendite tõlkimiseks võõrapärastamist: võõrapärastav tõlge esines vaid 7\%-1 juhtudest. Võõrapärastamise tagasihoidlikku kasutamist võib seletada sellega, et võõrapäraste elementide olemasolu tekstis nõuab vaatajalt rohkem vaimseid pingutusi, kuna nad tõmbavad paratamatult vaataja tähelepanu saate sisult kõrvale. Metafoori võõrapärastavat tõlget kasutati enamasti juhtudel, kus ei sobinud ei kodustav ega neutraalne lahendus, näiteks mittekonventsionaalse või kontekstiga tihedalt seotud keeruka metafoori puhul.

Käesolevas uurimuses arvati võõrapärastava tõlke hulka kõik lahendused, mille tulemuseks oli väljend, mida ei esine sihtkeele kõneleja tavalises kõnepruugis. Seejuures ei võetud arvesse, kas võõrapärane element oli tekkinud tõlke tulemusel või kanti lähtetekstist üle, kas tõlkija on sihtkeele norme rikkunud teadlikult või kogemata. Seega on võõrapärasuse käsitlus käesolevas uurimuses laiem kui Venuti mudelis, kus võõrapärastamine on eelkõige sihtkeele normide teadlik rikkumine, mille eesmärgiks on anda märku originaalteksti pärinemisest teisest kultuurist.

Uurimuse autorid on jõudnud ka järelduseni, et suhted lähte- ja sihtkeele vahel võivad olla keerulisemad kui Venuti mudelis. Lähte- ja sihtkeelt võib tugevalt mõjutada mõni kolmas keel, milleks eesti-vene tõlke puhul on inglise keel. Lisaks sellele võivad lähte- ja sihtkeel teineteist mõjutada, mida on näha eesti keele ja eestivenelaste vene keele näitel. Need keelekontaktid raskendavad võõrapärasuse määra hindamist.

Uurimuses kasutati võõrapärasuse hindamiseks lisaks kvalitatiivsele ka kvantitatiivset meetodit ehk kontrolliti metafoori esinemissagedust keelekorpuses ja internetis. Väljendi suhtelise esinemissageduse uurimine annab võimaluse välja arendada võõrapärastamise hindamise kvantitatiivsed kriteeriumid. Samas kaasnevad selle meetodi kasutamisega eesti-vene tõlke puhul mõned probleemid. "Pealtnägija" peamine auditoorium on eestivenelased, kelle vene keel on eesti keele mõju all paljuski muutunud ning seetõttu võivad nad tajuda harjumuspärasena ka selliseid metafoore, mis Venemaa venelastele tunduvad võõrapärased. Siiski on keelekorpuste kasutamine hea abivahend metafooride tõlke analüüsil. 
Uurimuse põhjal võib väita, et Venuti kodustamise ja võõrapärastamise opositsioon on sobiv instrument metafooride tõlke uurimiseks eesti-vene tõlkesuunal. Kuigi uurimus näitas, et eesti-vene meediatõlkes püütakse võõrapärastavat lahendust pigem vältida, õnnestus autoritel just võõrapärastava tõlke rühmast leida tõlke probleemseid kohti, mis valmistavad tõlkijatele raskusi. Tõlkemeetodite analüüs kodustamise ja võõrapärastamise seisukohast võib aidata tõlkijal läheneda tõlkeprotsessile teadvustatumalt ning arendada välja raskete kohtade ületamiseks vajalikud tõlkestrateegiad, et saavutada soovitud tulemus, mis parandab kokkuvõttes meediatõlke kvaliteeti.

\author{
Aadress: \\ Ekaterina Kornilitsina, Ingrid Rummo \\ Tartu Ülikool \\ Eesti ja üldkeeleteaduse instituut \\ Jakobi 2, IV korrus \\ 51014 Tartu, Eesti \\ E-post: kornil@ut.ee, ingrid.rummo@ut.ee
}

\title{
Kirjandus
}

Baker, Mona (2007) "Reframing conflict in translation". Social Semiotics 17 (2), 151-169.

Bassnett, Susan and Andre Lefevere (1990) Translation, history and culture. London: Printer Publishers.

Belikova, Alexandra (2010) "Poliittinen metafora suomi-venäjä-käännöksissä: Kognitiivinen lähestymistapa". MikaEL Kääntämisen ja tulkkauksen tutkimuksen symposiumin verkkojulkaisu. Electronic proceedings of the KäTu symposium on translation and interpreting studies 4. <http://www.sktl.fi/@Bin/40672/Belikova _MikaEL2010.pdf >. Vaadatud 09.11.2016.

EKSS $=$ Eesti keele seletav sõnaraamat. $<$ http://www.eki.ee/dict/ekss/>. Vaadatud 09.11.2016.

ERR-i statistika $=$ ERRi telekanalite vaadatavuse statistika septembris. $<$ http://info.err. ee/v/statistika/f412d267-e157-4fb8-99af-4897254b92e8/erri-telekanalite-vaadatavuse-statistika-septembris>. Vaadatud 09.11.2016.

Jõesaar, Andres (2015) “Telekanalite vaadatavus Eestis enne ja pärast 28. septembrit”. Riigikogu Toimetised 32/2015: 39-45.

Kaldjärv, Klaarika (2007) Autor, jutustaja, tõlkija. Borgese autofiktsioonid eesti keeles. Doktoritöö. Tartu: Tartu Ülikooli Kirjastus. <http://www.ekl.ee/tolkijad/up/uploads/ Kaldjarv.pdf>. Vaadatud 09.11.2016. 
Lakoff, George ja Mark Johnson (2011) Metafoorid, mille järgi me elame. Tallinn: Tallinna Ülikooli Kirjastus.

Lakoff, George (1992) “The contemporary theory of metaphor”. In Andrew Ortony, ed. Metaphor and thought (2nd edition), 202-251. Cambridge: Cambridge University Press.

Munday, Jeremy, ed. (2009) The Routledge companion to translation studies, revised edition, Oxon: Routledge.

Myskja, Kjetil (2013) "Foreignisation and resistance: Lawrence Venuti and his critics". Nordic Journal of English Studies 12(2): 1-23. <http://ojs.ub.gu.se/ojs/index.php/ njes/article/view/2201/1957>. Vaadatud 09.11.2016.

Molina, Lucia and Amparo Hurtado Albir (2002) "Translation techniques revisited: a dynamic and functionalist approach". Meta XLVII, 4, 498-512.

Pedersen, Jan (2005) "How is culture rendered in subtitles?" MuTra 2005 - Challenges of Multidimensional Translation: Conference Proceedings, 1-18. $<\mathrm{http}: / / \mathrm{www}$. euroconferences.info/proceedings/2005_Proceedings/2005_Pedersen_Jan.pdf $>$. Vaadatud 09.11.2016.

Penttilä, Esa and Pirkko Muikku-Werner (2012) "Domestication and foreignization in figurative idiom translation”. In Hannu Kemppanen, Marja Jänis, Alexandra Belikova, eds. Domestication and foreignization in translation studies, 121-138. Berlin: Frank \& Timme.

Schleiermacher, Friedrich (2005) "On the different methods of translating". In André Lefevere, ed. Translation/history/culture: a sourcebook, 141-166. London, New York: Routledge.

Tymoczko, Maria (2012) "Tõlkimine ja poliitiline angažeeritus. Aktivism, sotsiaalne muutus ja tõlkimise roll geopoliitilistes nihetes". Methis. Studia humaniora Estonica 2012, 9/10, 165-188.

Venuti, Lawrence (1998) The scandals of translation: Towards an ethics of difference. London: Routledge.

Venuti, Lawrence (2008) The translator's invisibility. London \& New York: Routledge. Verschik, Anna (2016) "Mixed copying in blogs: evidence from Estonian-Russian language contacts". Journal of Language Contact 9, 186-209.

VKRK $=$ Vene keele rahvuslik korpus = Nacional'nyi korpus russkogo jazyka.

$<$ http://ruscorpora.ru/>. Vaadatud 09.11.2016.

\begin{abstract}
Ekaterina Kornilitsina, Ingrid Rummo: Lawrence Venuti's dichotomy of domestication and foreignization as a research instrument for translation methods of metaphor in Estonian-Russian translation. Estonian - Russian media translation occupies an important place in the cultural space of Estonia, although there are only a few studies on this translation direction. One of the instruments that may help a translator to choose between possible solutions is the translation dichotomy of domestication and foreignization by the American translation theorist Lawrence Venuti. This opposition connects the choice of a translation method with the cultural
\end{abstract}


context of the translated text. Venuti's dichotomy is used in contemporary translation research to study various text elements, among them metaphor. Metaphor is considered to be one of the most complex translation objects due to its remarkable cross-cultural variation. This article discusses the use of Venuti's dichotomy for researching the translation methods of metaphors in the Estonian-Russian translation of the TV programme "Pealtnägija" ("Spectator"). Although the preferred translation method was domestication, foreignization was also widely used for unconventional, context-related and borrowed metaphors.

Keywords: domestication, foreignization, media translation, Estonian-Russian translation, Lawrence Venuti, metaphor, translation method 